症例報告

\title{
Shy-Drager 症候群における麻酔中の血行動態
}

\author{
青山幸生* 釜野安昭* 岡本章宽* \\ 永田勝太郎* 浅利 遥* 村山良介*
}

要旨 Shy-Drager 症候群は, 中枢性の自律神経失調症であり ${ }^{1)}$, 厚生省の特定疾患に指定されてい る.

本症候群では，体位変換に伴う血圧の変動が著しく，従って麻酔中は体位変換により血行動態が 大きく影響されることが予想されるが，その詳細な報告は少ない.

今回，57歳女性の本症患者で鼓室形成術の麻酔を行うにあたり，麻酔前後の血行動態および術中 のホルモン動態を測定しえたので報告する.

\section{はじめに}

Shy-Drager 症候群 (SDS) は，1960年に Shy と Dragerによりはじめて記載された症候群で, 起立性低血圧, インポテンツ, 排尿障害, 発汗 異常など多くの自律神経症状と両側性の運動系 神経症状, パーキンソン様症状など多彩な症状 を伴う症候群である11.

SDSに対しては麻酔管理上, 自律神経系の抑 制による循環系の autoregulation の破綻が特に 問題となり, 麻酔中の体位変換は殊に血行動態 に大きな影響を及ぼすと考えられる。

今回我々は, Parama GP303S 自動血圧計, NCCOM (non-invasive continuous cardiac out put monitor, BoMed 社製) を用いて, 術 前, 術中の血行動態を測定し, またホルモン動 態も測定しえたので報告する.

*東邦大学大橋病院麻酔科学研究室

受理日 1989.3 .1

\section{症例}

57 歳女性, 身長 $160 \mathrm{~cm}$, 体重 $60 \mathrm{~kg}$ 。昭和 62 年よ り, 立ち眩み, めまい等が出現し, SDS と診断 され，昇圧薬 (複数) の大量投与を受けていた。 起立性低血圧 (I 型, 起立直後型) は残存, その 他頻尿, 動悸, 耳鳴, 頭痛等自律神経症状は持 続していた. 今回慢性中耳炎の治療のため当院 耳鼻科に入院, 鼓室形成術を施行する事になっ た。

麻酔科外来における術前の Shellong's tilting test (active tilting test) では, 起立直後に収 縮期血圧, 1 回心拍出量の低下, 心拍数, 総末 梢循環抵抗の上昇を認めた（表 1 ）。

手術当日, 手術室入室 30 分前に硫酸アトロピ ン $0.5 \mathrm{mg}$, ハイドロキシジン $50 \mathrm{mg}$ 筋注し, 入室 後モニターとして, 心電図, 観血的動脈圧を測 定した。麻酔導入前に Shellong's tilting test (passive tilting test $30^{\circ}$ ) を行い, 循環系の各 
表 1 Shellong の起立試験（既に昇圧薬使用中）（active tilting test）

\begin{tabular}{|l|c|c|c|c|c|c|}
\hline & supine & standing (直後) & $3^{\prime}$ & $5^{\prime}$ & $8^{\prime}$ & $10^{\prime}$ \\
\hline BP & $146 / 88$ & $120 / 88$ & $130 / 92$ & $122 / 91$ & $135 / 83$ & $140 / 93$ \\
HR & 60 & 75 & 69 & 70 & 69 & 70 \\
SV & 103 & 68 & 70 & 62 & 85 & 77 \\
CI & 3.7 & 3.1 & 2.9 & 2.6 & 3.5 & 3.3 \\
SVR & 1390 & 1600 & 1750 & 1860 & 1370 & 1610 \\
\hline
\end{tabular}

measured by Parama GP303S,NCCOM

$\mathrm{BP}:$ blood pressure $(\mathrm{mmHg}), \mathrm{HR}:$ heart rate $(\mathrm{B} / \mathrm{min}), \mathrm{SV}:$ stroke volume $(\mathrm{m} \ell)$,

$\mathrm{CI}:$ cardiac index $\left(\ell / \mathrm{min} / \mathrm{m}^{2}\right)$, SVR $:$ systemic vascular resistance $\left(\right.$ dyne $\left.\cdot \sec \cdot \mathrm{cm}^{-5}\right)$

表 2 全身麻酔下での術中血行動態 (m-NLA+GO)

\begin{tabular}{|l|c|c|c|c|c|c|}
\hline & supine & $30^{\circ}$ tilting & I' & $2^{\prime}$ & $3^{\prime}$ & '' \\
\hline BP & $112 / 96$ & (passive) & $88 / 64$ & $98 / 68$ & & $80 / 60$ \\
HR & 72 & & 51 & 53 & 測 & 54 \\
SV & 40 & & 51 & 43 & 定 & 50 \\
CI & 1.8 & & 1.6 & 1.4 & 能 & 1.5 \\
SVR & 2830 & & 2230 & 2730 & & 2200 \\
\hline
\end{tabular}

パラメータ，ホルモン動態を測定し，循環動態 の安定を確認してから後フェンタニール $300 \mu \mathrm{g}(5$ $\mu \mathrm{g} / \mathrm{kg})$, ジアゼパム $5 \mathrm{mg}$, サイオペンタール 125 $\mathrm{mg}$ により麻酔を導入し, サクシニールコリン 60 $\mathrm{mg}$ で気管内捜管, GO で麻酔を維持した。呼吸は 調節呼吸とした，導入直後より血圧は低下した が, 輸液速度を速めたところ徐々に血圧は回復 し, 収縮期血圧120～130mm $\mathrm{mg}$ の間で安定した. 血圧の安定したところで第 2 回目の Shellong's tilting test (passive tilting test $30^{\circ}$ )を行い, 1 回目同様の項目について測定したが, tilting 開 始 3 分後血圧測定不可能となり, 体位を水平臥 位にもどすとともに，点滴速度を速めたところ 約 2 分後に収縮期血圧 $100 \mathrm{mmHg}$ 前後に回復し た。その間昇圧薬は使用しなかった（表 2 ）。

手術開始後, 血圧の上昇をみたので, 麻酔を $\mathrm{GO}$ エンフルレンで維持し,手術終了まで血圧の 変動はあったものの著しい低血圧をきたすこと
はなかった。その間昇圧薬の使用はなかった。

手術経過に伴う内分泌反応は, 麻酔開始前で は, 起立負荷により，コルチゾール，レニン活 性, アンギオテンシン I, II の上昇が, 術中に おいても同様の結果が得られた。また麻酔覚醒 時においては, コルチゾール, アドレナリン, アルドステロンの上昇がみられ，上昇した諸ホ ルモンは, 術後 3 時間で前值に復した. 血中力 テコラミンレベルは, 術中低値を示した(表 3 ).

\section{考 察}

起立時の血圧調節には，圧反射弓を介する交 感神経系の働きが重要であり，この圧反射弓の どこかがなんらかの原因で障害をうけると起立 性低血圧が出現する2).

本症では, 術前の Shellong's tilting test (active tilting test) で，昇圧薬大量投与中にも かかわらず，起立直後に血圧の低下を生じ，10 
表 3 手術経過に伴う内分泌反応

\begin{tabular}{|c|c|c|c|c|c|c|c|c|}
\hline & \multicolumn{2}{|c|}{ 麻酔導入前 } & \multirow{2}{*}{$\begin{array}{c}\text { 挿管後 } \\
5 \text { 分 }\end{array}$} & \multirow{2}{*}{$\begin{array}{l}\text { 手 術 } \\
\text { 終了時 }\end{array}$} & \multirow{2}{*}{$\begin{array}{l}\text { 麻 酔 } \\
\text { 覚醒時 }\end{array}$} & \multirow[b]{2}{*}{$\mathrm{I} \mathrm{hr}$} & \multirow{2}{*}{$\begin{array}{r}\text { 術 } \\
2 \mathrm{hr}\end{array}$} & \multirow{2}{*}{ 後 $3 \mathrm{hr}$} \\
\hline & supine & standing $30^{\circ}$ & & & & & & \\
\hline Cortisol ( $\mu \mathrm{g} / \mathrm{d} \ell)$ & 14.4 & $16.7 \uparrow$ & 8.1 & $19.3 \uparrow$ & $26.4 \uparrow$ & 4.4 & 2.5 & 3.1 \\
\hline \multicolumn{9}{|l|}{ Catecholamine $(\mu \mathrm{g} / \mathrm{m} \ell)$} \\
\hline Adrenaline & 0.01 & 0.02 & 0.01 & 0.02 & $0.27 \uparrow$ & 0.05 & 0.03 & 0.06 \\
\hline Noradrenaline & 0.18 & 0.26 & 0.18 & 0.20 & 0.22 & 0.26 & 0.19 & 0.10 \\
\hline Dopamine & 3.8 & 3.8 & 2.3 & 2.7 & 2.7 & 2.8 & 2.8 & 2.8 \\
\hline Aldosterone $(\mathrm{pg} / \mathrm{m} \ell)$ & 36 & 81 & 27 & 47 & $93 \uparrow$ & 35 & $10>$ & $10>$ \\
\hline Renin activity $(\mathrm{ng} / \mathrm{m} \ell / \mathrm{hr})$ & 0.7 & $4.3 \uparrow$ & $6.2 \uparrow$ & $5.4 \uparrow$ & 2.0 & $12 \uparrow$ & 3.1 & I.I \\
\hline Angiotensin I $(\mathrm{pg} / \mathrm{m} \ell)$ & 64 & $320 \uparrow$ & $420 \uparrow$ & $260 \uparrow$ & 44 & $640 \uparrow$ & 200 & 94 \\
\hline Angiotensin II $(\mathrm{pg} / \mathrm{m} \ell)$ & 8 & $30 \uparrow$ & 21 & $38 \uparrow$ & 18 & $69 \uparrow$ & 28 & 15 \\
\hline $\operatorname{ACE}\left(I U / \ell / 37^{\circ} \mathrm{C}\right)$ & 13.3 & 13.4 & 11.3 & 11.6 & 12.3 & 11.6 & 10.9 & 10.3 \\
\hline
\end{tabular}

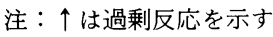

分後に前值に復している ( I 型：起立直後型). このタイプは血圧調節において，特に中枢に問 題があり ${ }^{3)}$, Shy \& Dragerの言う中枢神経系の 障害を伴った起立性低血圧とよく一致している. また Shellong's tilting test (passive tilting test $30^{\circ}$ )を用いた麻酔前と麻酔中での血行動態の変 化の比較では, 麻酔中の変動が大きく, しかも 特徵として, 著しい低血圧, chronotropic action の低下, 低心拍出量, 高総末梢循環抵抗などが 認められた。

また過去の本症例麻酔報告によると，いずれ の麻酔法においても, 術中低血圧をきたしてお り, その際の昇圧薬の選択が重要であり, しか も昇圧薬に対する反応は, 各症例において無反 応，過剰反応とまちまちであり，術前より昇圧 薬効果を確認しておくことが必要であると思わ れる4) 8).

今回の我々の症例では, 血行動態が悪化して も速やかに体位を水平臥位にもどすことにより， 血行動態の改善が認められた。すなわち，いず れの症例にも共通してはいるが, 本症例におい ては, 特に体位の安定維持が最も重要であり, かつ体位変換時の急速な血圧低下に対しては,
体位を水平臥位にもどす事が第一義的であると 考えられた。

近年本症候群においては, 交感神経終末から のノルアドレナリン遊離の低下が指摘されてお り，血中カテコラミンがその診断および予後判 定に有用とされている。しかし血中ノルアドレ ナリン值は正常とする報告8) 11)や, 低值とする報 告2)等まちまちである.

本症例では, 麻酔導入前と後に tilting test （passive tilting test $30^{\circ}$ ) の負荷を与えて，カ テコラミンの反応性を検討したが，ノルアドレ ナリンをはじめ, アドレナリン，ドーパミンと もに低值を示し，カテコラミンの遊離が不十分 で，正常人と比べ容易に循環調節不全による低 血圧が生じ易いと考えられた。特に，ノルアド レナリンは, 術前, 中, 後を通じて常に低値で あり，麻酔薬をはじめとする種々の薬物のもつ 血管拡張作用や心筋抑制作用に加え，体位変換 や陽圧呼吸, 出血などによる静脈還流を阻害す る因子に対しての, 代償機構の低下に留意する ことが必要であると思われた。

最後に本症例のように自律神経系に障害を有 する疾患では, 術前にあらかじめ有効な昇圧薬 
を確認しておく事や, Shellong's tilting test 等 の自律神経負荷試験を行い, 循環系の反応，予 備能を知っておくことは有用ではあるが，必ず しも術中の反応を予測する事はできない.その ためにも，術中十分なモニタリングのもとに， 輸液, 輸血を過不足なく行い体位変換等必要な 場合は，慎重に行うことが必要であると思われ る.

この論文の要旨は, 第 8 回日本臨床麻酔学会 （宮崎市）に於て発表した。

\section{参考文献}

1) Shy GM, Drager GA : A neurological syndrome associated with orthostatic hypotension: A clinical pathologic study. Arc Neurol $2: 511 \sim 527,1960$

2 ) 関谷達人, 風谷幸男, 橋本治久ほか: Shy-Drager 症候群 の一例一圧反射弓を中心とした病態機序の検討一. 臨床 と研究 $59: 170 \sim 174,1982$

3 ）永田勝太郎：起立性低血圧. 自律神経 $22(4) ： 320 \sim 330$, 1985
4) 篠原正一, 硲久子, 野崎京子: 表皮水泡症およびシャイ・ ドレーガー症候群患者の麻酔経験. 麻酔 $23: 765 \sim 771$, 1974

5 ) 沼尻康男, 渋谷正直, 吉田和政ほか：Shy-Drager 症候群 の麻酔経験. 臨床麻酔 $6: 682 \sim 692,1982$

6) 奥田剛久, 畑野研太郎, 北村豊ほか：Shy-Drager 症候群 患者の麻酔経験。麻酔 $28: 859 \sim 864 ， 1979$

7 ) Cohen CA : Anesthetic management of a patient with the Shy-Drager syndrome. Anesthesiology 35 : 95 97, 1971

8 ）中村治正, 河野克涁, 奥谷龍ほか: Shy-Drager 症候群に おける術中カテコラミンレベル. 臨床麻酔 10 ： 1045〜 1098, 1986

9) Kopin IJ, Polisky RJ, Oliver JA, et al. : Urinary catecholamine metabolities distinguish different types of synpathetic neural dysfunction in patients with orthostatic hypotension. J Clin End and Metab $57: 632 \sim 637,1983$

10) Ziegler MC, Lake CR, Kopin IJ : The sympathetic nervous system defect in primary orthostatic hypotension. N Engl J Med 296 : 293 297, 1977

11) Gross G, Nagel-Hiemke $M$, Krause $\mathrm{KH}$ : Plasma catecholamines during activation of the sympathetic nervous system in a patient with Shy-Drager syndrome. J Neurol $224: 125 \sim 131,1980$

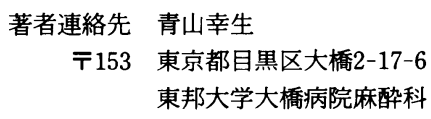
東邦大学大橋病院麻酔科

\title{
Hemodynamics in Patient with Shy-Drager Syndrome during Anesthesia
}

\author{
Yukio AOYAMA, Yasuaki KAMANO, Akihiro OKAMOTO \\ Katsutaro NAGATA, Haruka ASARI, Ryosuke MURAYAMA \\ Department of Anesthesiology, Oohashi Hospital Toho University, School of Medicine
}

A 60-year-old female patient, being previously diagnosed as Shy-Drager-Syndrome (SDS), was scheduled for tympanoplasty.

Preoperatively, her hemodynamics and plasma catecholamines were evaluated both in supine and tilting position.

Blood pressure fell steeply with active tilting, and recovered with resuming her position. Plasma norepinephrine concentration remained low even in hypotensive state.

Induction of anesthesia with diazepam-fentanyl markedly pronounced these tendencies, however, they recovered to normal with postural correction and rapid fluid infusion.

We conclude that preoperative evaluation may provide favourable informations for management of the patients with autonomic nervous dysfunction accompanied with SDS.

The Journal of Japan Society for Clinical Anesthesia Vol. 9 No. 4, 1989 